Policy Model for Muslim State Inflation Control

\title{
POLICY MODEL FOR MUSLIM STATE INFLATION CONTROL
}

\author{
Hamdan Firmansyah \\ Darussalam Gontor University Ponorogo Indonesia \\ Email: abihilqi@gmail.com
}

\begin{abstract}
Inflation is a problem which is not simple and is classified as an economic disease. Inflation is one important indicator in analyzing a country's economy, especially with regard to its broad impact on macroeconomic variables: economic growth, external balance, competitiveness, and even income distribution. Inflation is characterized by high and continuous increases in prices not only causing some adverse effects on economic activity, but also on the prosperity of individuals and society. An increase in the price of one or two items alone cannot be called inflation, unless the increase extends to an increase in the majority of other goods.
\end{abstract}

Keywords: Inflation, Macro, Economy

\section{A. INTRODUCTION}

One of the most important monetary events that can be found in almost all countries in the world is inflation. A short definition of inflation is the tendency of prices to increase in general and continuously (Umaru \& Zubairu, 2012). An increase in the price of one or two goods alone is not called inflation, unless it extends to (or results in an increase in) a large part of the price of the other goods. The requirement for a continuous upward tendency also needs to be remembered. An increase in prices due to, for example, seasonality, before big holidays, or which occurs only once (and has no further effect) is not called inflation. This kind of price increase is not considered a problem or economic "disease" and does not require special policies to overcome it (Boediono, 2009).

Inflation is an economic phenomenon that is always interesting to discuss, especially in relation to its broad impact on the macro economy (Yolanda, 2017): economic growth, external balance, competitiveness, interest rates, and even income distribution. Inflation also plays a role in influencing the mobilization of funds through formal financial institutions (Huda, 2008). According to Adiwarman Karim, in general inflation is an increase in the general price level of goods / commodities and services over a certain period of time. Inflation can be considered a monetary phenomenon due to a decrease in the value of the monetary unit of calculation for a commodity (Karim, 2007).

According to Sadono Sukirno, inflation is a process of increasing prices prevailing in an economy (Sukirno, 2010). Paul A. Samuelson says:

By inflation we mean a time of generally rising prices for goods and factors of production-rising prices for bread, cars, haircuts; rising wages, rents, etc. By deflation we mean a time when most prices and cost are failing (Samuelson, 1999).

So in Paul A. Samuelson's perspective, inflation occurs when the level of prices and general costs increases; the price of rice, fuel, cars went up; the level of wages, land prices, and the rent of capital goods also rose. Meanwhile, deflation occurs when prices and costs generally fall.

Thus, inflation is a process or event of an increase in the general price level (Partadireja, 2006). In other words, too much money chasing after too little. Inflation usually refers to consumer prices, but can also use other prices International Journal of Nusantara Islam Vol.09 No.01 2021: (93-105) DOI: 10.15575/ijni.v9i1.11984 
(wholesale prices, wages, prices, assets and so on). Usually expressed as the percentage change in the index number. The price level soars to $100 \%$ or more in a year (hyperinflation), causing a loss of public confidence in the currency, so people tend to keep their assets in other forms, such as real estate or gold, which usually retain their value in times of inflation.

Inflation is less dangerous if it is predictable, because everyone will consider the prospect of higher prices in the future in making decisions. In reality, inflation is unpredictable, meaning people are often shocked by price increases. This reduces economic efficiency because people will take less risk to minimize the chance of losing a price shock. The faster the inflation rate increases, the more difficult it is to predict future inflation.

\section{B. METHOD}

This study uses a qualitative approach and descriptive methods, and was developed using literature studies in the form of books, literature or library materials to find expert opinions about a particular theme, then quote the opinions of these experts to strengthen the theoretical basis of research. The author analyzes and synthesizes various views and opinions of experts or the results of previous research, then the author describes and analyzes the research results and draws conclusions..

\section{RESULT AND DISCUSSION}

\section{a. Pengertian Inflasi}

In the Dictionary of Economics of Money and Bank, it is said that inflation is a condition in which the prices of goods in general have increased which is mainly because the supply of money far exceeds the demand for money (Sudarsono \& Edilius, 2001). The inflation expectation factor is influenced by the behavior of the public and economic actors in using inflation rate expectations in their decisions on economic activities.

According to the Keynesian Theory, inflation is caused by the behavior of a society who wants to live outside its economic limits. According to this view, this is part of the process of fighting over a share of sustenance among social groups who want a greater share than what can be provided by the community which causes a situation in which the demand for society increases to a greater extent than the supply of goods in the market. Meanwhile, according to Irving Fisher, inflation is defined as an increase in general prices caused by three factors, namely the money supply, the speed of money circulation, and the amount of goods being traded.

Inflation is the process of increasing the price of general goods that is valid in the economy. This does not mean that the prices of the various goods have increased by the same percentage. What is important is that there is an increase in the general price of goods continuously for a certain period. The increase that occurred only once (although with a fairly large percentage) was not inflation (Sukirno, 2011). Inflation usually refers to consumer prices, but can also use other prices such as wholesale prices, wages, prices, assets and so on.

Usually expressed as the percentage change in the index number. The price level soars to $100 \%$ or more in a year (hyperinflation), causing a loss of public confidence in the currency. Some economists argue that the economy will run efficiently if inflation is low. Ideally, macroeconomic policies should aim to stabilize prices. In addition, low inflation rates are considered by a number of economies to be a good thing if they occur as a result of innovation (Huda, 2009).

Inflation is a condition in which there is a sharp increase in the prices of goods and services (absolute) which takes place continuously and in a long period of time. The value of money has decreased sharply in proportion to the increase in prices. Meanwhile, deflation is a condition in which the prices of goods and services continue to decline sharply. Both can threaten and destroy the stability of a country's economy. Inflation and deflation are measured from the overall prices of goods and services. Furthermore, Tajul Khlawaty defines inflation as a 
condition that indicates the weakening of purchasing power followed by a decline in the real value of a country's currency (Khalwaty, 2000).

According to Nopirin, inflation is a process of increasing prices in general and is continuously related to the market mechanism caused by several factors, among others, increased public consumption, excess liquidity in the market that triggers consumption and even speculation, including due to the lack of smooth distribution of goods (Nopirin, 1998). According to Mudrajad Kuncoro, inflation is: the tendency of prices to increase in general and continuously. An increase in the price of one or two goods cannot be called inflation, unless the increase is widespread or results in an increase in other goods (Kuncoro, 2001).

Inflation is defined as an increase in the prices of various commodities due to the weakening of the local currency exchange rate due to the large number of local currencies in circulation (Islam et al., 2017). Inflation will lead to a decline in economic performance, which is due to the real sector's declining performance (Sukirno, 2005). Boediono defines inflation as the tendency of prices to increase in general and continuously (Boediono, 1992).

According to Hadi Soesastro, inflation is a condition caused by an unbalanced demand for goods and supplies, namely demand exceeds supply and the greater the difference, the greater the danger posed by inflation for economic health (Soesatro, 2005). In simple terms, inflation is defined as an increase in prices in general and continuously. An increase in the price of one or two goods alone cannot be called inflation unless it extends (or results in price increases) to other goods.

b. Types of Inflation

Inflation can be divided into several types, among others:

1. Creeping inflation is usually characterized by a low inflation rate (less than $10 \%$ per year). Price increases are running slowly with a small percentage and a relatively long period of time.

2. Medium inflation (glopping inflation) is usually marked by a fairly large price increase (usually double digit or triple digit). The price increase took place in a relatively short time and is accelerating, the price this week / month is higher than last week or month.

3. High inflation (hyperinflation) is the most severe inflation, prices increase by 5 or 6 times. People no longer want to save money. The value of money has fallen sharply, the velocity of money is accelerating and prices are increasing at an accelerated rate (Samuelson \& Nordhaus, n.d.).

\section{c. Characteristics of Inflation}

There are at least three things that need to be emphasized in understanding inflation, namely (Nanga, 2001) :

1. There is a tendency for prices to increase, which means that the price level that occurs at a certain time is either up or down, but still shows an increasing tendency or tendency.

2. The increase in the price level occurs continuously (sustained), which means it does not occur at one time, but for several times. Temporary increases in prices, such as at certain moments such as holidays, cannot be said to be inflation.

3. The price level in question is the general price level, not just one or several commodities. An increase in the price of one or two goods alone cannot be called inflation unless the increase in price extends (or results in an increase) to other goods. 
The initial understanding of inflation put more emphasis on the value of money. The overall price level in the economy can be viewed from two sides, namely the price level as the price of a number of goods and services. When the price level rises, people have to pay more to buy goods and services. Alternatively, we view the price level as a measure of value for money. An increase in the price level means a lower value for money. If this is expressed mathematically, then consider $P$ to be the price level measured, for example by the consumer price index or the GDP deflator. Thus, $P$ measures the amount of money needed to purchase a number of goods and services. Reversed, the quantity of goods and services obtained for $\$ 1$ is $1 / P$. In other words, if $P$ is the price of goods and services measured in money value, then $1 / \mathrm{P}$ is the money value measured in terms of goods and services. This means that when the overall price level rises, the value of money falls (Mankiw, 2006).

From this description, there are three components that must be fulfilled in order to say that inflation has occurred, namely as follows (Prathama, 2008) : 1) An increase in prices. The price of a commodity is said to increase if it becomes higher than the price of the previous period (Rangasamy, 2017). 2) General. An increase in the price of a commodity cannot be said to be inflation if the increase does not cause prices in general to rise. 3) Going on continuously. A general price increase will not cause inflation if it occurs only for a moment. Therefore, the calculation of inflation is carried out within the minimum monthly timeframe.

d. Causes of Inflation

Awareness of the bad consequences of inflation, encourages experts to try to explain the causes of inflation, namely as follows:

1. Demand pull inflation, this inflation usually occurs when the economy is growing rapidly. High employment opportunities create high levels of income and in turn lead to expenditures that exceed the economic capacity of producing goods and services. This excessive spending can lead to inflation. Demand Pull Inflation is inflation that occurs due to excess demand for goods and services. The excess demand that these producers cannot meet will certainly drive up prices, because demand is greater than supply. Look at the following graph:

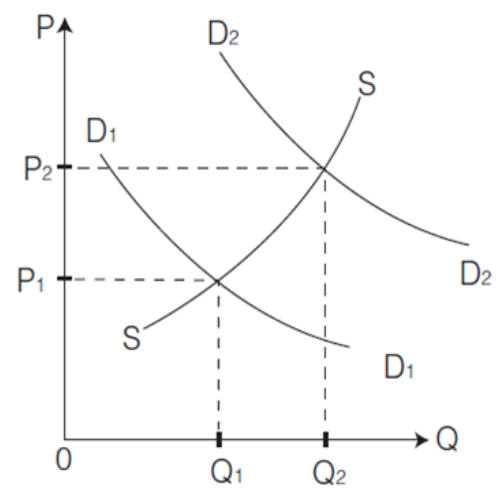

Figure 1: Demand Curve

From the figure, it can be seen that due to increased demand, the demand curve shifts from D1D1 to D2D2. This shift resulted in prices rising from OP1 to OP2.

2. Cost push inflation, this inflation also occurs when the economy is developing rapidly when the number of unemployed is very low. So that it causes an increase in production costs which results in reduced purchasing power. Cost push inflation is inflation that occurs due to an increase in production costs. Increased production costs will push up the prices of goods and services. In addition, an increase in production costs will result in a decrease in the amount of production so that supply becomes reduced, 
if supply decreases while demand is assumed to be constant, the price will rise as a result. Look at the following graph:

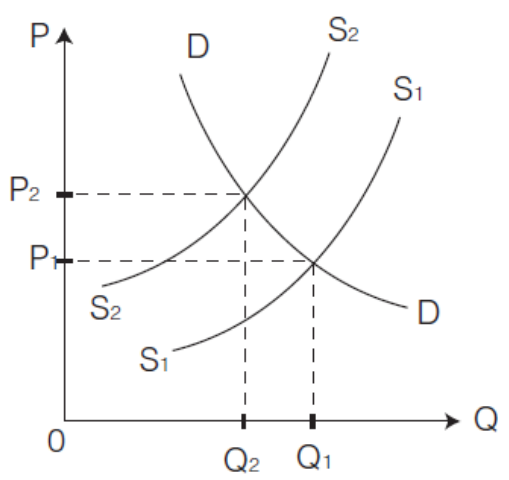

Figure 2: Supply Curve

From the figure it appears that due to the increase in production costs, the supply curve shifts from S1S1 to S2S2. This shift resulted in prices rising from OP1 to OP2.

3. Imported inflation, this inflation occurs when imported goods experiencing price increases have an important role in company expenditure activities (Sukirno, 2005).

e. Inflation Impact

The impact of inflation that can occur in an economy is:

1. Inflation can encourage redistribution of income in society (redistribution effect of inflation).

2. Inflation can cause a decrease in economic efficiency. This can occur because inflation directs productive investment resources to unproductive investment so that it will reduce the capacity of the productive economy (efficiency effect of inflation).

3. Inflation leads to changes in output and employment (Thayaparan, 2014). This happens because by motivating the company to produce more or less than what it is capable of and at the same time motivating people to work more or less than what has been done so far (output and employment effect of inflation).

4. Inflation can create an unstable environment for economic decisions (Nanga, 2001).

\section{f. Policies to Overcome Inflation}

Achieving continuous zero percent inflation in a developing economy is difficult to achieve. Therefore, in the long run what needs to be done is to keep the inflation rate at a very low level. To maintain economic stability, the government needs to carry out a policy to reduce the inflation rate because after all the government has an important role in controlling the inflation rate because inflation occurs or not depends on government policies in running the economy. The policies used to overcome the problem of inflation are fiscal policy and monetary policy (Amassoma et al., 2018).

\section{Fiscal policy}

Etymologically, fiscal policy comes from two words, namely policy and fiscal. Policy (policy) is given a variety of meanings, Harold D. Laswell and Abraham Kaplan give the meaning of policy as a program to achieve goals, values and directed practices (Islamy, 2003). An expert, James E. Anderson, formulating policies as the behavior of a number of actors (officials, groups, government agencies) or a series of actors in a particular field 
of activity (Wahab, 2005). Fiscal, namely 1) related to financial matters; 2 ) at this time the term fiscal is used in a special meaning as opposed to "monetary". Fisc is related to "fisc", namely the financial aspect of government (Winardi, 2011), while fiscal policy is a demand management instrument that seeks to influence the level of economic activity through tax control and government expenditure (Collins, 1994).

In terminology, according to Mustafa Edwin Nasution, in conventional economics fiscal policy can be interpreted as government steps to make changes in the tax system or in spending (in a macro concept it is called government expenditure) (Nasution, 2006). According to Eko Suprayitno, fiscal policy is a policy taken by the government to spend its income in realizing economic goals (Suprayitno, 2005). According to Sadono Sukirno, fiscal policy is the government's steps to make changes in the tax system or in spending with a view to overcoming the economic problems faced (Sukirno, 2010). Fiscal policy includes the steps the government takes to make changes in the field of taxation and government spending with a view to affecting aggregate (overall) spending in the economy.

It can be concluded that fiscal policy is a policy in budget revenues and expenditures that makes the budget balance, deficit, or surplus. In fact, fiscal policy has long been known in Islamic economic theory, namely since the time of the Prophet and Khulafaur Rasyidin, and was later developed by scholars. Ibn Khaldun (1404) proposed a solution to the recession in the form of reducing taxes and increasing government spending, the government is the largest market, the parent of all markets, in terms of revenue and revenue. If the government market has decreased, it is only natural that other markets will also decline, even in a larger (overall) aggregate. "Laffer, the economic adviser to President Ronald Reagan, who discovered the Laffer's Curve theory, said he was taking Ibn Khaldun's idea.

In addition, Abu Yusuf (798) was the first economist to write specifically about economic policy in his book, alKharaj, which explained the economic responsibility of the government to meet the needs of its people. Abu Yusuf strongly opposed the taxation on agricultural land and suggested that it be replaced with agricultural zakat linked to the amount of his crop. Abu Yusuf made details of how to finance the construction of bridges, dams and irrigation (Karim, 2001). At the time of the Prophet Muhammad, the revenue side of the APBN consisted of kharaj (a type of land tax), zakat, kums (tax I/ 5), jizyah (a type of tax on non-Muslim bodies), and other revenues (including kaffarah / fines). .

On the expenditure side, it consists of expenses for the interests of da'wah, education and culture, science and technology, defense and security, social welfare, and personnel expenses (Karim, 2007). Zakat and kums receipts are calculated proportionally, that is, as a percentage and not a nominal value is determined. In macroeconomic terms, this will create a built in stability. It will stabilize prices and suppress inflation when aggregate (overall) demand is greater than aggregate supply. In a state of stagnation, for example, aggregate demand falls to be smaller than aggregate supply, it will lead to the stability of income and total production. The commercial zakat system will not affect the price and quantity offered because zakat is calculated from the results of the business.

In financial terms it is called tax on quasi rent. This is different from the current popular value added tax (VAT) system; VAT is calculated on the price of goods so that prices are more expensive and the quantity offered is less or in economic terms, up ward shift on the supply curve. Especially for zakat on livestock, Islam applies a progressive system to provide incentives to increase production. The more livestock you have, the lower the zakat rate to be paid. It will encourage the achievement of a larger production scale and create production cost efficiencies. This progressive system only applies to zakat on livestock because if there is an excess supply, the livestock will not rot like vegetables or fruits. Prices will not fall due to excess supply. 
Good administration is proven to generate trust for the people who pay zakat and vice versa. In the time of Umar ibnul Khaththab, the receipt of baitul mal reached 160 million dirhams; in the time of al-Hajaj it only reached 18 million dirhams; and in the time of Umar ibn Abdil Aziz it rose to 30 and 40 million dirhams in the first and second years of his reign. On the expenditure side, infrastructure development has received great attention. Umar ibnul Khaththab ordered Amr ibn Ash, Governor of Egypt, to spend a third of the state budget for this. He excavated a canal from Fustat (Cairo) to Suez to facilitate trade transportation between the Arabian Peninsula and Egypt. Also the construction of two business cities: Kufa (for business with Rome) and Basrah (for business with Persia) (Karim, 2001).

The APBN rarely experiences a deficit, that is, expenditures can only be made if there is revenue. Once experienced a deficit, namely before the Hunain War, but it was paid off immediately after the war. In the days of Umar and Uthman R.A, the APBN even experienced a surplus. No deficit means that no new money will be printed and this means that inflation will not occur due to monetary expansion. Inflation occurred at the time of the Prophet and Khulafaur Rashidin due to the decline in the supply of goods during the dry season or during the war.

\section{Monetary policy}

Etymologically, the word monetary means something that has something to do with currency (Habeyb, 1980), related to money or finance. There are also those who define monetary to mean "everything about money" (Simorangkir, 1985). Similarly, S. Wojowasito defines monetary as "about money or finances (Wojowasito, nd). Meanwhile, the monetary system means a general term that includes policies and actions that affect a particular country's currency (Winardi, 2005).

In relation to human needs, people who live in a country need economic stability. One of the ways to stabilize a country's economy is through the right monetary policy. In terminology, Boediono formulated: Monetary policy is the action of the government or the central bank to influence the macro situation which is carried out through the money market. This is the general definition of monetary policy. More specifically, monetary policy can be interpreted as a macro action by the government (central bank) by influencing the money creation process. By influencing the money creation process, the government can influence the money supply (Boediono, 2009)

Meanwhile, Nopirin defines monetary policy as actions taken by the monetary authorities (usually the central bank) to influence the amount of money in circulation which in turn will affect the economic activities of the community. The objective of monetary policy, particularly for economic stabilization, can be measured by employment opportunities, price stability and a balanced international balance of payments. If stability in economic activity is disturbed, monetary policy can be used to restore (stabilization action) (Nopirin, 1998).

The issue of money is not only important in relation to the national economy, but also in relation to the world economy. It is very important for a country to ensure the stability of the price of its money and if possible increase the price of this money in relation to the price of foreign money abroad. One of the efforts to achieve this goal is financial politics, which becomes the monetary economy environment (Manullang, 1980). In the beginning, money was secondary to economic theory. But gradually it is an important thing or part of economic theory. Because money is an important tool in the economic traffic of a country, and its influence is very large.

\section{g. Al-Maqrizi's Opinion on Efforts to Suppress Inflation}

The methods and methods used by Al-Maqrizi six hundred years ago are still relevant today, Al-Maqrizi argues that the impact of hyperinflation that hit the Egyptian economy at that time was caused by inefficient government administration and the carrying out of extraordinary crimes. bribery, commercialization of office, collusion, nepotism and at the same time repressive taxes imposed by the government that are not accountable to the 
people are detrimental to the incentives of farmers to work, and ultimately cause a significant decline in agricultural production as the dominant sector of life at the time. that. If we correlate it with Indonesia as an agricultural country, rich in natural resources. So the concept of Al-Maqrizi is appropriate to be implemented in the welfare of society through reforming government administration that is clean from extraordinary crimes.

Meanwhile, Al-Maqrizi divides Egyptian society into seven social strata groups with the aim of knowing which strata group feels the impact of hyperinflation more. The first group is the ruler and his servants (ahlud daulah). The second group is businessmen, big traders and people who live in luxury (ahlul yasar). The third group is the middle class of entrepreneurs and traders including professionals (așhābul hirfah). The fourth group is farmers who generally live in rural areas. The fifth group is the destitute group which according to Al-Maqrizi are all fuqoha, students, and soldiers. The sixth group is manual laborers and fishermen. And finally the seventh group is the poor and beggars.

After dividing into several groups, Al-Maqrizi emphasized the intensity of the pain and suffering he experienced as a result of hyperinflation. And the group that feels more suffering with hyperinflation is the fifth group because their income in the form of wages and salaries is fixed. As for the sixth and seventh groups, not only feel the suffering of hyperinflation but also can be said to die of hunger.

\section{h. M. Umer Chapra's Opinion on Efforts to Suppress Inflation}

M. Umer Chapra's opinion regarding efforts to reduce inflation is that there must be price stability, and a strategy. This is as stated by Chapra: "The alternative policy that is best and in accordance with the norms of socioeconomic justice emphasized by sharia is price stability. According to Chapra, the strategy to reduce inflation is first, moral improvement (which is pursued not only in the material dimension but also spiritually).

"The most important element of the Islamic strategy for realising the Islamic goals is the integration of all supposedly mundane aspects of life with the spiritual to bring about a moral uplift of the human being and the society in which he lives. Without such a spiritual uplift, none of the goals can be realised and true human welfare would be difficult to attain" (Chapra, 1985).

Second, an even distribution of income and wealth.

"Hence, the second important ingredient of the Islamic strategy is that it has provided a blueprint for the reorganisation of all aspects of life, whether economic, social or political, to enable them to strengthen the moral fibre of society and to actualise the goals so dear to Islam. For example, equitable distribution of income and wealth, the claimed objective of all economic systems, cannot be realized without: (a) a belief in the brotherhood of mankind, which can meaningfully spring only from a belief in the One God Who has created all human beings and before Whom everyone is equal and fully accountable; (b) a socio-economic system which does not create the social-Darwinist attitude of survival of the fittest, but reorganises society on moral foundations to foster socio-economic interaction based on justice and cooperation; (c) a socio-political system which prevents injustice and exploitation through various ways, including the prohibition of riba, and makes the material support of the weak and the down-trodden amoral obligation of the individuals, the society and the state. Wi.th the progress of the discussion in this book, it will gradually become clearer how Islam can ensure the realisation of its goals" (Chapra, 1985).

According to Chapra, Islam has also outlined the processes and mechanisms for distributing wealth among all levels of society in order to create justice and prosperity (Yuliadi, 2001). Enforcement of rules in the distribution of wealth fairly will keep the possibility of income inequality among members of the community. On the one 
hand, there are opportunities and opportunities for individuals who are creative and have the potential to have large amounts of wealth without having to carry out improper economic practices such as monopoly, KKN, etc. unable to meet their basic needs.

Third, the elimination of usury.

"Some major elements of the strategy for the reform of the money and banking system (for example, abolition of riba and profit-and-loss sharing) have been prescribed by the Quran and the Sunnah. Other elements have to be designed by the Muslim countries depending on their circumstances and their relative position on the path of goal actualisation. The parts of the strategy prescribed by the Qur'an and the Sunnah are indispensable and beyond dispute. The crucial test for other elements of the strategy will, however, be the support they provide to the overall strategy of the Shari'ah and the contribution they make to the realisation of the goals. The stronger the support provided and the greater the contribution made toward the ultimate objective, the more desirable would be the man-made elements of the strategy provided that they are not in conflict with the Shari'ah. Such man-made elements of the total strategy cannot be a one-time affair. They would need to be continually improved and perfected through a process of evolution" (Chapra, 1985).

Islam and all the Shari'a Samawi prohibits usury because it causes social and economic dangers. From a social perspective, people cannot take the slightest advantage of usury practices (Al-Assal \& Karim, 1980). From an economic point of view, usury is an unhealthy way of doing business. The benefits obtained do not come from productive work which can increase the wealth of the nation. However, the profit was only for himself without any economic reward. This profit is only obtained from a number of assets taken from the borrower's assets, which actually does not increase the assets of the person making usury.

According to Chapra, inflation means that money cannot be used as a fair and honest exchange rate. This makes money an unfair means of payment for deferral of payments and an untrustworthy store of value. Money can make some people dishonest with others, even if unwittingly, by silently undermining the purchasing power of monetary assets.

\section{i. Author Opinion on Efforts to Suppress Inflation}

Inflation arises due to pressure from the supply side (cost push inflation), from the demand side (demand pull inflation), and from inflation expectations. The factors of cost push inflation can be caused by the depreciation of the exchange rate, the impact of foreign inflation, especially trading partner countries, increases in government-regulated commodity prices (administered prices), and negative supply shocks due to natural disasters and disruption of distribution.

The factor that causes demand pull inflation is the high demand for goods and services relative to their availability. In the macroeconomic context, this condition is described by real output that exceeds potential output or the total demand (aggregate demand) is greater than the capacity of the economy. Meanwhile, the inflation expectation factor is influenced by the behavior of the public and economic actors in using inflation rate expectations in their decisions on economic activity. These inflation expectations are more likely to be adaptive or forward looking.

This is reflected in the behavior of price formation at the producer and trader levels, especially in the lead-up to religious holidays (Eid, Christmas and New Year) and the determination of the provincial minimum wage (UMP). Although the general availability of goods is estimated to be sufficient to support the increase in demand, the prices of goods and services during religious holidays increase higher than the supply-demand condition. Likewise, at the time of determining the UMP, traders also increased the price of goods even though the wage increase was not too significant in driving an increase in demand. 
Inflation control through monetary policy, which is the country's politics in determining regulations and actions in the field of state finances. More specifically, monetary policy has the meaning of government macro actions through the central bank by influencing money creation. By influencing the money creation process, the government can influence the money supply, which in turn can affect investment spending, then influence aggregate demand and finally the price level so as to create the desired economic conditions.

Monetary policy in Islam is based on the following basic principles of Islamic economics; (a) The highest power belongs to Allah and Allah is the absolute owner (b) Man is the Leader (caliph) on earth, but not the true owner (c) Everything that is owned and obtained by humans is because of the permission of Allah, and therefore you are -the less fortunate siblings have the right to part of the wealth owned by their more fortunate brothers (d) Wealth should not be accumulated or hoarded (e) Wealth must be rotated (f) Eliminating the gap between individual differences in the economy, can eliminate conflicts between groups ( $\mathrm{g}$ ) Establishing obligations which are obligatory and voluntary for all individuals, including for members of the community who are poor. In the technical aspect, Islamic monetary policy must be free from elements of usury and bank interest.

Conventional banks cannot prosper mankind, on the contrary, Islamic banks aim to prosper mankind in this world and safety in the hereafter. Muslims must change the financial system, especially in the banking sector. for the revival of the Islamic ummah must be carried out gradually and there is no need to rush. However, to build an Islamic-style banking system, we do not have to wait until the revival of Muslims.

j. Author Stability

The author's findings from several research results from international journals are used as a basis for ideas in the problem of inflation.

1. Ditimi Amassoma, Keji Sunday, Emma-Ebere Onyedikachi, The influence of money supply on inflation in Nigeria. University of Economics in Katowice: Journal of Economics and Management Vol. 31 (1) 2018: The purpose of this study is to empirically investigate the effect of the money supply on inflation in Nigeria. This study was born out of a curiosity to re-examine the direct causes of Nigeria's alarming inflation rate which adversely affects the general welfare of the Nigerian population. The results show that the money supply does not really affect inflation in both the long and short term perhaps because the country is in a recession. The error correction model has a true negative sign and this means that it is significant that approximately $21 \%$ of errors are corrected annually. The results of the Granger causality show that, there is no causal relationship between the money supply and inflation in Nigeria in the study period and vice versa. The implication of this is that there are often different economic conditions which are the main determinants of inflation in Nigeria. This study recommends that the government should diversify the economy, minimize imports by encouraging the production of local products and services.

2. A. Thayimpa, Impact of Inflation and Economic Growth on Unemployment in Sri Lanka: A Study of Time Series Analysis. (USA) Global Journal of Management and Business Research: B Economics and Commerce. Volume 13 Issue 5 Version 1.0 Year 2014: Examining the effect of inflation and economic growth on unemployment in Sri Lanka for the period 1990-2012. In order to achieve this objective, secondary data has been drawn from the annual reports of the Central Bank for the above periods. The regression results reveal that the inflation coefficient is negative and statistically significant effect on unemployment, while the gross domestic product is positive but does not have a significant effect on unemployment. Finally, the research concludes that only inflation significantly reduces unemployment and gross domestic product has a positive but insignificant effect on unemployment. The result of causality proves that there is only one-way causality between inflation and unemployment, but there is a two-way causality between unemployment. 
3. Logan Rangasamy, The impact of petrol price movements on South African inflation. South Africa: Journal of Energy in Southern Africa Vol 28 No 1 February 2017: Analyzing the impact of gasoline price movements on inflation outcomes in South Africa since the mid-1970s. The results show that, over time, the direct contribution of gasoline inflation to the headline inflation has not only increased, but has also exceeded its weight in the consumer price index. In addition, the Granger causality test reveals that the price of gasoline has an important influence on the prices of other commodities (nongasoline) in the economy. The basic results show that the increase in the price of gasoline has an important effect on the outcome of inflation in South Africa. This implies that gasoline price movements require special attention in policy.

4. Imoto Tatsuyoshi, Trend Inflation and Monetary Policy Regimes in Japan. RIETI Discussion Paper Series 18-E-024 April 2018: Discusses the dynamics of inflation trends in Japan over the last three decades based on the Phillips curve transition model. We find that there is a strong relationship between inflation trends and monetary policy. The results show the importance of exchange rates in explaining recent inflation fluctuations and the importance of oil and stock prices in maintaining a positive trend inflation regime.

5. Rabiul Islam, Ahmad Bashawir Abdul Ghani, Emil Mahyudin, Narmatha Manickam, Determinants of Factors that Affecting Inflation in Malaysia. International Journal of Economics and Financial Issues, 7 (2), 2017: Inflation has become a serious problem over a period of time. It can be said that, over the last few years, Malaysian inflation was caused by many factors. The aim of this paper is to determine the factors affecting inflation in Malaysia. This paper consists of quantitative methods and an econometric model used to identify the relationship between the dependent and independent variables. Two models can be categorized in this paper, namely mathematical models and econometric models. In this paper, autocorrelation, multicollinearity, and heteroscedasticity have been discussed. High inflation can have a negative impact on certain countries.

6. Y. Yolanda, Analysis of Factors Affecting Inflation and its Impact on Human Development Index and Poverty in Indonesia. European Research Studies Journal Volume XX, Issue 4B, 2017: This study aims to analyze the effect that occurs between Bank Indonesia $(\mathrm{BI})$ - exchange rates, foreign exchange rates, money supply, oil prices and gold prices on inflation, their impact on the Development Index. Humans (HDI) and poverty in Indonesia for the period 1997 to 2016 . This study uses secondary data with a purposive sampling method. The data analysis method uses multiple regression analysis, Model 1: The results of this study indicate that there are simultaneously significant variables in the $\mathrm{BI}$ Rate, Foreign Exchange Rates, Money Supply, oil prices and gold prices to the inflation rate in Indonesia. The results also showed that the BI rate, money supply, oil price and gold price variables had a positive and significant partial effect on the inflation rate, while the exchange rate variable did not affect the inflation rate. The coefficient of determination of the results of 0.9497 means that the ability of the independent variable to explain the dependent variable is $94.97 \%$, while the remaining $5.03 \%$ is influenced by other variables and is not included in this study. Model 2: inflation on the HDI is significant and positive and model 3 : Inflation in poverty is significant and positive.

The author gives the idea that low and stable inflation is a prerequisite for sustainable economic growth which in turn provides benefits for improving people's welfare. The importance of controlling inflation is based on the consideration that high and unstable inflation has a negative impact on the socio-economic conditions of society.

The characteristic of inflation in Indonesia still tends to fluctuate, which is mainly influenced by the supply side (supply side) due to disruptions to production, distribution and government policies. In addition, shocks to inflation can also come from government policies related to prices for strategic commodities such as fuel and other energy commodities (administered prices). 
Based on the characteristics of inflation, which is still susceptible to shocks, to achieve low inflation, inflation control requires cooperation and coordination between agencies, namely between Bank Indonesia and the Government. Especially empowering and developing the existence of Islamic Financial Institutions that are resistant to inflation. Banking activities must still refer to the provisions and provisions of sharia. Unlike the case with conventional banking, which creates a large gap between the real sector and non-real sector activities which lead to inflation.

It is hoped that with this harmonization and synchronization of policies, low and stable inflation can be achieved which in turn supports the welfare of the community.

\section{CONCLUSION}

In terms of inflation, it is a continuous increase in prices within a certain period of time. Inflation can be divided into several types, among others: creeping inflation, which is characterized by an increase in prices running slowly with a small percentage and a relatively long period of time. Glopping inflation is marked by an increase in prices running in a relatively short period of time and is accelerating, the price this week / month is higher than the previous week or month. Hyperinflation is characterized by a sharp decline in the value of money, the velocity of money faster and the price to increase at an accelerated rate. The policies used to overcome the problem of inflation are fiscal policy and monetary policy.

Umer Chapra's opinion regarding efforts to reduce inflation, namely that there must be price stability, and strategies to reduce inflation, namely through improving morale, equitable distribution of income / wealth and eliminating usury. Al-Maqrizi argued that the impact of hyperinflation that hit the Egyptian economy at that time was caused by inefficient government administration and the committing of extraordinary crimes. So the right model is to be implemented in the welfare of the community through reforming government administration that is clean from extraordinary crimes.

To overcome the impact of inflation, the Islamic economy recommends changing paper currency (fulus) into gold and silver again and prohibiting excessive imports so as not to choke domestic producers themselves. Muslims must change the financial system, especially in the banking sector because Islamic banks aim for the welfare of mankind in the world and safety in the hereafter.

\section{REFERENCES}

Al-Assal, A. M., \& Karim, F. A. A. (1980). Al-Nizam al-lqtisadi Fi al Islam Mabadi Uhu Wahdafuhu (A. Ahmadi \& A. U. Sitanggal, Trans.). PT. Bina llmu.

Amassoma, D., Sunday, K., \& Onyedikachi, E.-E. (2018). The influence of money supply on inflation in Nigeria. University of Economics in Katowice. Journal of Economics and Management, 31(1).

Boediono. (1992). Teori Pertumbuhan Ekonomi. BPFE.

Boediono. (2009). Ekonomi Makro. BPFE.

Chapra, M. U. (1985). Towards a Just Monetary System. The Islamic Foundation.

Collins. (1994). Kamus Lengkap Ekonomi. Airlangga.

Huda, N. (2008). Ekonomi Makro Islam. Kencana.

Huda, N. (2009). Ekonomi Makro Islam: Pendekatan Teoritis. Kencana Prenada Media Group. 
Islam, R., Ghani, A. B. A., Mahyudin, E., \& Manickam, N. (2017). Determinants of Factors that Affecting Inflation in Malaysia. International Journal of Economics and Financial Issues, 7(2).

Islamy, M. I. (2003). Prinsip-prinsip Perumusan Kebijaksanaan Negara. Bumi Aksara.

Karim, A. A. (2001). Ekonomi Islam Suatu Kajian Kontemporer. Gema Insani Press.

Karim, A. A. (2007). Ekonomi Makro Islam. PT Raja Grafindo Persada.

Khalwaty, T. (2000). Inflasi dan Solusinya. PT Raja Grafindo Persada.

Kuncoro, M. (2001). Manajemen Keuangan Internasional. BPFE.

Mankiw, N. G. (2006). Pengantar Ekonomi Makro. Salemba Empat.

Manullang, M. (1980). Ekonomi Moneter. Ghalia Indonesia.

Nanga, M. (2001). Makro Ekonomi: Teori, Masalah dan Kebijakan. PT Grafindo Media Pratama.

Nasution, M. E. (2006). Pengenalan Eksklusif Ekonomi Islam. Kencana.

Nopirin. (1998). Ekonomi Moneter. BPFE.

Partadireja, A. (2006). Pengantar Ekonomika. BPFE.

Prathama, R. (2008). Pengantar IImu Ekonomi (Mikro Ekonomi dan Makro Ekonomi),. Lembaga Penerbit Fakltas Ekonomi Universitas Indonesia.

Rangasamy, L. (2017). The impact of petrol price movements on South African inflation. . . South Africa: Journal of Energy in Southern Africa, 28(1).

Samuelson, P. A. (1999). Economics. McGraw-Hill Book Co.

Samuelson, P. A., \& Nordhaus, W. (n.d.). Ekonomi 1. Erlangga.

Soesatro, H. (2005). Pemikiran dan Permasalahan Ekonomi di Indonesia. Erlangga.

Sudarsono, \& Edilius. (2001). Kamus Ekonomi Uang dan Bank. Rineka Cipta.

Sukirno, S. (2005). Dasar-Dasar Ekonomi Makro. BPFE.

Sukirno, S. (2010). Pengantar Teori Makro Ekonomi. Raja Grafindo Persada.

Sukirno, S. (2011). Makro Ekonomi Teori Pengantar (3rd ed.). Rajawali Press.

Thayaparan, . (2014). Impact of Inflation and Economic Growth on Unemployment in Sri Lanka: A Study of Time Series Analysis. Global Journal of Management and Business Research: B Economics and Commerce, 13(5).

Umaru, A., \& Zubairu, A. A. (2012). Effect of Inflation on the Growth and Development of the Nigerian Economy (An Empirical Analysis). USA: International Journal of Business and Social Science, 3(10).

Wahab, S. A. (2005). Analisis Kebijaksanaan dari Reformulasi ke Implementasi Kebijaksanaan Negara. Bumi Aksara.

Winardi. (2005). Kamus Ekonomi Inggris-Indonesia. ALUMNI.

Winardi. (2011). Kepemimpinan dalam Manajemen. PT Rineka Cipta.

Yolanda, Y. (2017). Analysis of Factors Affecting Inflation and its Impact on Human Development Index and Poverty in Indonesia. European Research Studies Journal, XX(4B). 